\title{
Moving from Ecological Conservation to Restoration: An Example from Central Taiwan, Asia
}

\author{
Yueh-Hsin Lo', Yi-Ching Lin², Juan A. Blanco ${ }^{3}$, \\ Chih-Wei $\mathrm{Yu}^{4}$ and Biing T. Guan ${ }^{1, *}$ \\ ${ }^{1}$ National Taiwan University, \\ ${ }^{2}$ Tunghai University, \\ ${ }^{3}$ University or British Columbia \\ ${ }^{4}$ New Taipei City Government \\ 1,2,4Taiwan \\ ${ }^{3}$ Canada
}

\section{Introduction}

The concept of "natural conservation" has been evolving since the beginning of the first efforts to preserve the natural landscape. The creation of the first national parks in the $19^{\text {th }}$ century was originated by the belief that landscapes of exceptional beauty should be preserved from human influence and maintained in their current state for the enjoyment of future generations (Runte, 1997). During the first years of the establishment of national parks around the world, defining these "exceptional landscapes" was usually based on the static beauty of the area: majestic mountains, glaciers, old forests, gorges, canyons, waterfalls, etc. The protection in these areas was basically achieved through the prevention of creating human structures in the sites, reducing and controlling human activity and, in practice, maintaining the areas as they look at the time when they were declared as protected. Therefore, this protection was not based on ecological considerations, but on a human-centered view of natural sites.

The type of protected ecosystems varied widely among regions, depending on the history of human impact on them. For example, national parks in North America were created to protect largely untouched, almost pristine landscapes practically unaffected by the low populations of native peoples previous to European contact (Runte, 1997). Similarly, in South America and Africa, large natural areas could still be found during the $19^{\text {th }}$ and $20^{\text {th }}$ centuries were the human impact was thought to be minimal. However, in Europe or Asia, were the history of urban development can be traced back for millennia and the density of population is also higher, it was more difficult to found those untouched areas. As a consequence, national parks were created to protect landscapes of indisputable beauty but usually with a noticeable human influence on them. Ecosystems at this time of early

${ }^{*}$ Corresponding Author 
conservation efforts were seen as static entities, that should not be altered or they would lose their integrity. However, with the arrival of modern ecology, this static view was gradually substituted by the classic view of gradual linear change along a continuum, arriving to a single climax state (Clements, 1916; Odum, 1969; Pickett and McDonnell, 1989). This climax state was usually identified with the state that nature reaches in absence of human influence, and therefore the efforts were oriented into maintaining it. As a consequence of this human-centered vision to define the areas to protect, regions such as oceans, deserts, swamps, shrublands and other similar ecosystems were usually considered "badlands" and unworthy of legal protection. On the other hand, very few protected areas have been established in productive landscapes with clear economical potential for agriculture or forest management (Scott et al., 2001). Even today, these regions are still underrepresented in the protected areas around the globe (Noss et al., 1995). Since the Rio Earth Summit in 1992, the global network of protected areas has continued to grow steadily, increasing yearly by an average $2.5 \%$ in total area and $1.4 \%$ in numbers of sites, and by 2006 covering more than 24 million $\mathrm{km}^{2}$ in about 133,000 designated sites (Butchard et al., 2010). Protected areas overall remain a core element of biodiversity conservation (Andam et al., 2008; Gaston et al., 2008).

During the $20^{\text {th }}$ century urban development was extended to all the regions of the world. With a booming human population and the intensification of economic development (first in Europe and North America and lately in the rest of the world) practically all the ecosystems in the world were impacted in one way or another. Therefore, it was just a matter of time that some of the iconic wildlife species of the world started to suffer from fast reductions in their populations, or even facing extinction. The danger of losing species such as whales, lions, tigers, elephants, panda bears, gorillas, brown bears, buffalos, sequoias, etc. was and still remains very real (Laliberte \& Ripple, 2004; Sanderson et al., 2008). This danger was highlighted by scientists and environmental managers around the world, and the society responded with the creation of environmentalist groups, whose social pressure helped to create lists of endangered animal and plant species needing specific actions for conservation. This was the base to develop programs and activities focused on the protection of individual high-profile species. Many of these campaigns were supported by the public due to the easy sympathy or spiritual connection with some of these majestic species, and as a consequence, natural conservation was seen by the main public as "avoiding things getting worse". Some of these activities have achieved important successes, such as the halt in commercial hunting of whales (Stevick et al., 2003), the breeding programs of panda bears (Peng et al., 2001) or the increase in numbers of American buffalos (Waldman, 2001). However, in other cases the protection of the target species was not enough to prevent its decline or extinction (e.g. the Yangtze River dolphin, Turvey et al., 2007; or the Pyrenean wild goat, Folch et al., 2009), or just the species were not interesting enough for the public opinion and therefore not the main focus of protection efforts, such in the case of "ugly" species as it is amphibians, reptiles, insects, cacti, etc.

The improvement of this species-oriented conservationism from the first days of creation of protected areas is that it recognizes individual species as worth of the preservation, even if they are not in "beautiful landscapes" with some sort of legal protection. Therefore, it moves one step from the human-centered conservation of some specific favourite areas to protect species and control the factors that affect their populations. However, the main drawback of this type of ecological conservation is that it is targeted to one species, not to the ecosystem that supports that species. This species-oriented conservation followed the theory that if the 
causes of non-natural mortality are controlled (i.e. hunting, harvesting, poaching, poisoning, clear-cutting, etc.), and the availability of resources increased, the target species could survive or even increase its population. Therefore, actions such as banning hunting, stopping illegal logging, controlling access to the areas were the species is distributed can be part of this strategy (Folch et al., 2009). In addition, zoos, herbariums, arboretums and other centers where collections of plant and animals are kept under controlled conditions are an important part of this strategy, as they provide research insights in the biology of the species and they can specially increase the population sizes of plants and animal species (Bagarinao, 1998).

However, actions that could be beneficial for the target species are not necessary relevant for other species in the ecosystem, and they could be ineffective if the ecosystem is too altered to keep the target species, even after removing the human factors directly affecting it. Ultimately, any plant, animal or microorganism species will survive in a given ecosystem as long as the right conditions exist to support the niche that the species inhabits. Conservation paradigms, practices, and policies have shifted over time recognizing this need to preserve the ecosystem and not just the target species (Adams, 2004). As a consequence, a more holistic approach to conservation has emerged since the last quarter of the $20^{\text {th }}$ century. Within this approach, the actions in the conservation effort will be directed to keep the integrity (bio-physical diversity) and the functionality of the ecosystem. This new approach is in the origin of the last trend in conservation: ecological restoration.

Ecological restoration involves assisting the recovery of an ecosystem that has been degraded, damaged, or destroyed, typically as a result of human activities (Sala et al., 2000). Ecological restoration is based on the new view of ecosystems as biological communities established on a geophysical substrate that can develop into alternative stable states rather than into a single climax state (Lewontin 1969). As a consequence, the idea of the balance of nature has been replaced with the flux of nature (Wu \& Loucks, 1995; Pickett \& Ostfield, 1995; Wallengton et al., 2005), and ecosystems are thought to be mostly in non-equilibrium. Their dynamics are not only complex but also dependent on the spatial context and the history of natural disturbance and human influence (Hobbs \& Cramer, 2008). The main implication of this conceptual model is that ecosystems that have been altered by human activity may not revert back to its original state if left alone. On the contrary, these altered ecosystems could just reach a different stable state defined by the actions of human management on them (i.e. soil alteration and erosion, invasive species, lost of native species, changes in hydrological regime, etc.). Examples of such alternative states are grasslands or forest dominated by invasive species or shrublands that substitute forests. The goal of ecological restoration is therefore the reestablishment of the characteristics of an ecosystem, such as biodiversity and ecological function that were prevalent before degradation (Jordan et al., 1987), and that will not be reached (or if so, in very long time scales) by the ecosystems if left alone.

Ecological restoration is different from the earlier protection of specific areas because "restoration" means human intervention to bring the ecosystem back to a state different from the one in which it is currently. Therefore, it is not a passive conservation effort in which humans are just consider outsiders that should not be "in the way" of Nature. Quite differently, ecological restoration needs direct human actions (i.e., modification of the physic-chemical environment, introduction of lost species, removal of invasive species, plantation of trees and plants, etc.). In addition, ecological restoration is different from conservation of emblematic species in that restoration targets the whole ecosystem, 
assuming that if the correct ecological conditions are maintained, the emblematic species (and their companion species) will be preserved in the restored area.

Ecological restoration has developed quickly since the first meetings of the Society of Ecological Restoration International in the early 1990s (Greipsson, 2011). Ecological restoration, both within and outside protected areas, is being increasingly applied worldwide (Clewell \& Aronson, 2007; Nelleman \& Corcoran, 2010), and it is increasingly found as part of natural resource management plans. Actions such as targeted habitat management, removal of invasive species, captive breeding, seed production and species reintroduction have yielded notable successes: among many examples, at least 16 bird species extinctions have been prevented by such means between 1994 and 2004 (Butchart et al., 2006).

Large-scale ecosystem restoration is needed to arrest and reverse the degradation of landscapes around the world (Manning et al., 2006). However, restoration efforts to date have been criticized for being ad hoc, site and situation specific (Hobbs \& Norton, 1996), or focusing on small, protected nature reserves (Naveh, 1994; Soulé \& Terborgh 1999). Hence, the effectiveness of restoration actions in increasing the provision of both biodiversity and ecosystem services has not been evaluated systematically. A meta-analysis of 89 restoration assessments in a wide range of ecosystem types across the globe indicated that ecological restoration increased the provision of biodiversity by $44 \%$ and ecosystem services by $25 \%$, but values of both remained lower in restored versus intact reference ecosystems (ReyBenayas et al., 2009). Although small-scale restoration projects can be valuable, there is an urgent need to greatly expand the scale of ecosystem restoration for both conservation and production (Naveh, 1994; Hobbs \& Norton, 1996).

From these results, it is clear that detailed field research is needed to guide restoration efforts. Field experiments can be a useful guide as to which restoration practices are the most useful for achieving this goal (Kimmins et al., 2010). In this chapter we describe the field research done to guide the restoration of native conifer forests in central Taiwan. Our research has as main objective the identification of the best conditions for seedling establishment of two tree native species: the evergreen Fabaceae Lithocarpus castanopsisifolius and Lithocarpus kwakamii (stone oak) in a former plantation of Japanese cedar (Cryptomeria japonica), an species alien to Taiwan. In this study, we seek to evaluate whether the combination of selective cutting, direct seeding, and understory vegetation control can be a cost-effective method to gradually restore plantation forests to native forests. We also seek to identify the potential barriers that hinder seed and seedling survival.

\section{An example from central Taiwan}

\subsection{Historical background}

Taiwan covers an area of $36,000 \mathrm{~km}^{2}$ and is located at the fringe of the Asian continental shelf at the western rim of the Pacific Basin, and separated from the main continent by a strait of $130 \mathrm{~km}$ in its narrowest point. The island has a very complex terrain, with about two thirds of Taiwan's land area at slopes over $10 \%$ and almost half of the island with slopes over 40\%, and with Jade Mountain (the highest peak), reaching $3952 \mathrm{~m}$ a.s.l. (Hsu \& Agaramoorthy, 1999). As a consequence of its insularity, closeness to the continent and wide gradient of altitudes, Taiwan harbours over 4,000 vascular plants in six different forest types (Boufford et al., 1996). Wildlife resources are also abundant with 61 species of mammals, 400 
species of birds, 92 species of reptiles, 30 species of amphibians, 140 species of fresh-water fish, and the estimated 50,000 species of insects including 400 species of butterflies (Hsu \& Agoramoorthy, 1997). To protect this rich biodiversity, the first national park was created in 1984 in Kenting (south Taiwan). Till date, 6 national parks, 18 nature reserves and 24 nature protected areas have been designated to ensure protection for wildlife and their habitats. The protected area covers $12.2 \%$ of the total land area of Taiwan (Hsu \& Agoramoorthy, 1999).

The history of forest conservation and restoration in Taiwan is closely linked to the economic development of the island. Timber harvesting peaked during the Japanese colonial period and immediately following World War II. Large areas of valuable timber, primarily cypress, spruce, and camphor, were cut and shipped primarily to Japan. Economic pressures led to an aggressive management, with plantations of native species and timber harvesting program through the 1950s to the 1970s, with an average of $1,552,600 \mathrm{~m}^{3}$ harvested from 1965 to 1975, corresponding to about 18,000 ha cut annually (Lu et al., 2001). These levels of harvesting brought petitions from citizens and environmental protection groups urging forest protection. This intensive level of exploitation was essentially halted with the national forestry management policy of 1976 (Wang, 1997). Since then, the emphasis of forest management in Taiwan has shifted almost entirely from timber production to forest protection. After 1977, timber was harvested mainly from forest plantations with an annual cut of about 100,000 $\mathrm{m}^{3}$ and by 1990, 99\% of Taiwan's timber supply was imported (Wang, 1997; Lu et al., 2001). Currently, national forest lands are managed almost exclusively for the purposes of streamflow regulation, erosion control, and conservation of biological diversity. Under this new approach, the harvesting-reforestation approach is no longer viable and alternatives need to be devised.

The interest on conservation is not limited to natural forests, but it is also extending into plantation forests, especially in the marginal plantations created during the $50 \mathrm{~s}$ and $60 \mathrm{~s}$, at the peak of exploitative management in the island. To restore and promote biodiversity, the current management directives mandate the restoration of plantations no longer serving for timber production back to native forests, in a gradual manner. One example is the important number of existing Japanese cedar (Cryptomeria japonica D. Don) plantations that were established in sites now considered as unsuitable for harvesting, mainly due to soil and slope protection concerns. This species was introduced from Japan with the start of the Japanese colonial rule at the end of the 19th century. It has become the most widely planted tree species in Taiwan, covering about $1.1 \%(41,132 \mathrm{ha})$ of the island's total land area (Taiwan Forestry Bureau, 1995). However, due to increasing production costs and declining timber prices, most of Taiwan's Japanese cedar plantations either are approaching or have passed the prescribed rotation age.

Knowledge on how to use current forestry practices to accelerate and support the conversion from plantations into native forests is needed to design successful restoration plans in these plantations. Among other concerns, it is necessary to understand the best ways of promoting native trees establishment. Seed and seedling survival are limited by multiple biotic and abiotic factors (Beckage et al., 2000; Fenner \& Thompson, 2005), making these stages the bottleneck of ecological restoration (Fenner \& Thompson, 2005; Leck et al., 2008). Drought, herbivory, and light are the three most important causes for seedling mortality (Leck et al., 2008)

To improve seed establishment rates, seedling planting and direct seeding are two common tools used in forest restoration. The former has the advantage of high success rate, but it is 
also more expensive than the later (Bullard et al., 1992). Direct seeding has the advantage in term of cost, but it usually has low success rates. Thus, the creation of an environment that enhances the survival of tree seeds and seedlings is a key element of a successful gradual forest restoration strategy. Selective cutting and thinning are common forestry practices that can also be used for restoration. During these procedures, only a portion of trees is removed, and the overall stand abiotic environment is not greatly altered. Therefore, partial removal of trees can enhance local light availability and create physical environments similar to natural gaps that are essential for seedling survival (Augspurger, 1984; Brokaw \& Busing, 2000; Masaki et al., 2007). In addition, the presence of understory vegetation may reduce seedling survival by reducing light availability or increasing competition between seedlings and understory vegetation (Leck et al., 2008). On the other hand, understory vegetation may reduce seedling predation by providing protection (Smit et al., 2006). Therefore, understory vegetation control may cast both positive and negative effects on the survival of seeds and seedlings (Beckage et al., 2000; Fenner \& Thompson, 2005; Leck et al., 2008).

\subsection{Material and methods}

\subsubsection{Experimental site}

This study was carried out in a 10-ha Japanese cedar plantation in the Heshe District of the

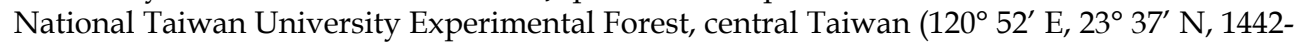
$1602 \mathrm{~m}$ a.s.l.; Fig. 1). Mean annual temperature of the study site is $19.8^{\circ} \mathrm{C}$, with a mean annual rainfall of $1500 \mathrm{~mm}$ (NTUF, 2011). Originally an evergreen broad-leaf forest dominated by Fagaceae and Lauraceae species, the site was clear-cut in 1958 and planted with

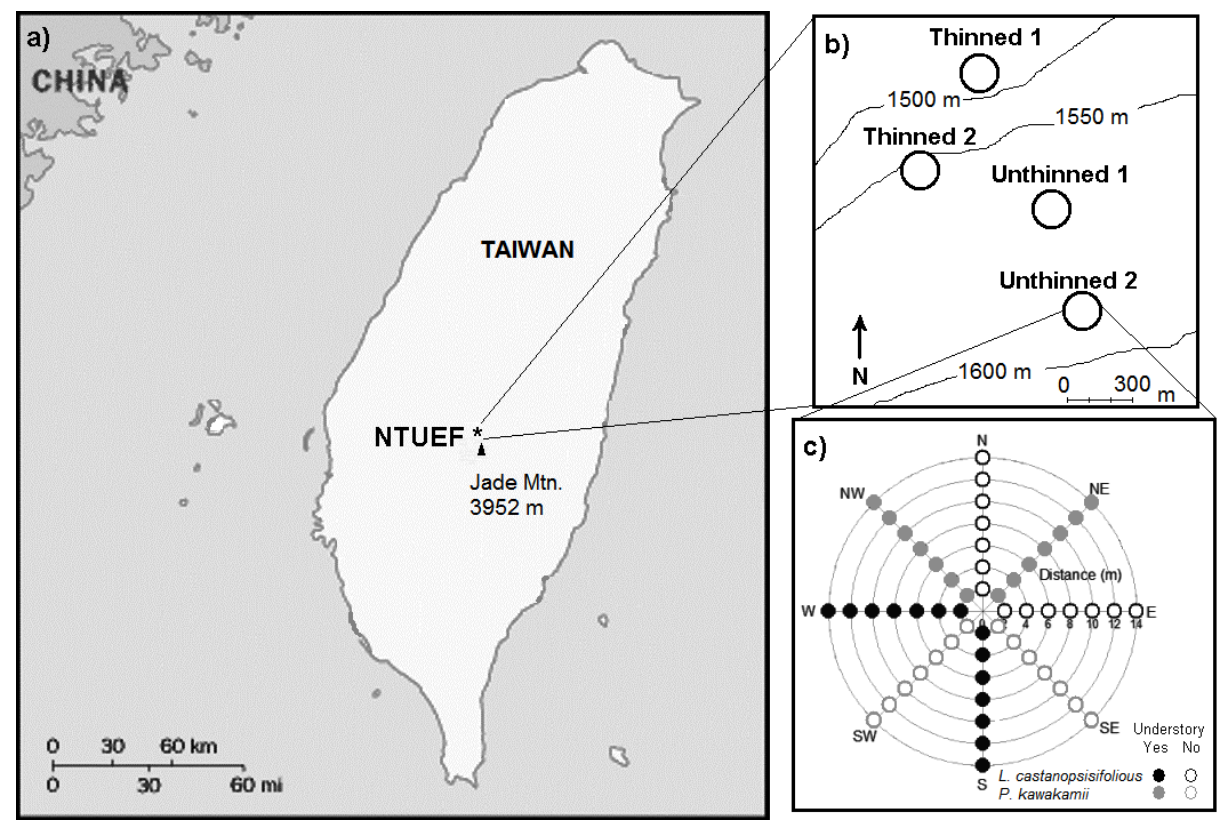

Fig. 1. Location of the experimental site, National Taiwan University Experimental Forest NTUEF (a), spatial arrangements of the treatment combinations (b), and seed transects (c). 
Chinese fir (Cunninghamia lanceolata). Due to typhoon damages in 1969, the stand was replanted with Japanese cedar in 1971. In 2005, the plantation was selected as a demonstration site to study how to gradually restore Japanese cedar forests back to native vegetation communities. Within 500-m from the edges of the plantation, remnants of the original vegetation can still be found. We regard those edge areas as the reference for the restoration project and to set the initial restoration goal: the successful establishment of late succession components of the reference stands in the plantation.

\subsubsection{Materials and experimental design}

An initial inventory found that while the saplings of late succession Lauraceae species (mainly dispersed by birds) were relatively abundant, only a few saplings of Fagaceae species were present. Thus, we focused only on the reintroduction of the main Fagaceae species. Lithocarpus castanopsisifolius (Hayata) Hayata and Pasania kawakamii (Hayata) Schottky were selected as the target species for reintroduction as they are late succession species and relatively abundant in the surrounding areas from were collected seeds. All fresh seeds used in this study were collected between October and November 2008 from the reference stands in the edges of the Japanese cedar plantation, and they were stored at $4{ }^{\circ} \mathrm{C}$ until they were used in January 2009.

As a part of the experiment, $20 \%$ of the standing volume was harvested to create gaps of different sizes. We established four plots, two thinned and two unthinned, within the plantation (Fig. 1b). The canopy openness of the two thinned plots was $27 \%$ and $29 \%$, whereas canopy openness of the two unthinned plots was $13 \%$ and $11 \%$. For each plot, a $10-$ meter transect was set at each of the 8 cardinal and inter-cardinal directions (Fig. 1c). The seeds of L. castanopsisifolius were placed along the cardinal direction transects, whereas the seeds of P. kawakamii were placed along the remaining four transects (Fig. 1c). For each group of transects in each plot (cardinal or inter-cardinal), we randomly selected two transects from where we removed the ground vegetation in a strip of 1-m wide along the entire transect (devegetated transects), whereas the ground vegetation of other two transects was left untouched (vegetated transects, Fig. 1c). Thus, the entire experiment consisted of 4 treatments for each species.

In January 2009 we placed 30 fresh seeds every $2.5 \mathrm{~m}$ along each transect, starting and ending at the $2.5-\mathrm{m}$ and $10-\mathrm{m}$ marks, respectively, for a total of 120 seeds per transect and 1920 seeds per species for the entire experiment. After placing the seeds, the number of seeds still present was counted every day during the first 35 days. After that, we went back on day 140 as the final checking time. At day 140, almost all the seeds were removed or consumed, therefore the experiment ended at that time.

Eight infrared automatic cameras, one for each species-treatment combination, were also set up to capture how the seeds were removed or consumed and by which animal species under different treatment conditions.

\subsubsection{Data analysis}

Cox regressions were used to analyze the survival and seedling establishment, with the hazard defined as the instantaneous mortality risk of a seed (Cox, 1972). The thinning and understory vegetation removal treatments were used as the explanatory variables. Species 
were analyzed separately. We used $\mathrm{R}$ to conduct all statistical analyses, with survival analysis using the R package Survival (R Core Team, 2010).

\subsection{Results}

\subsubsection{Field observations}

Seeds were first removed from transects with no ground vegetation cover (Fig. 2). Twenty days since the beginning of the observation, $82 \%$ and $48 \%$ of L. castanopsisifolius seeds were missing in the unthinned and thinned plots, respectively. These results were similar for the P. kwakamii seeds, with $95 \%$ and $48 \%$ seeds disappearing in the unthinned and thinned plots, respectively.

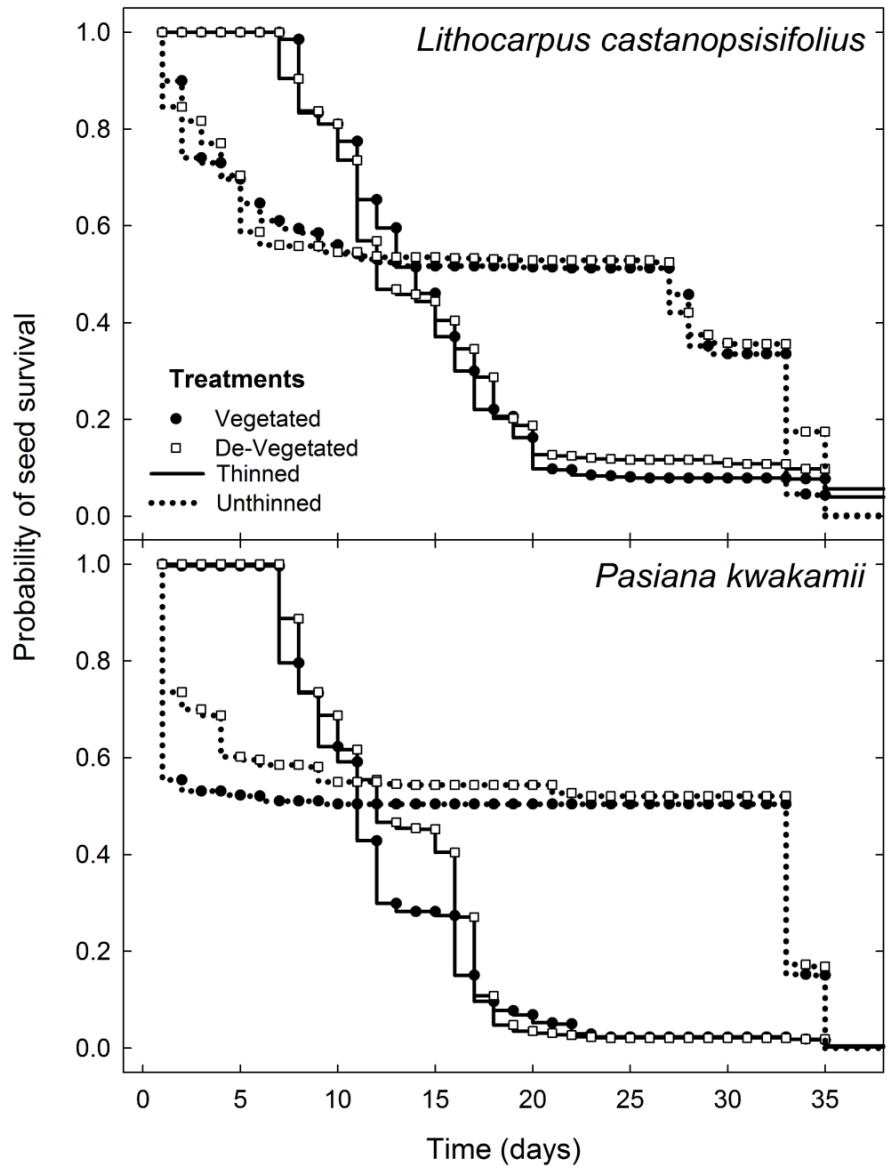

Fig. 2. Seed removal rates over a period of 61 days in different thinning and understory vegetation treatments for Lithocarpus castanopsisifolius (upper panel) and Pasania kawakamii (lower panel). Solid lines indicate thinned treatment, and dotted lines represent unthinned treatment. Solid black dots indicate ground vegetation intact, whereas opened squares represent without ground vegetation. 
Seeds of P. kwakamii were removed more slowly from the devegetated plots for both thinned and unthinned treatments, but this effect disappeared after 23 days of exposure. This pattern was not clearly identified for L. castanopsisifolius seeds, but after 15 days there seemed to be a tendency for a slightly higher probability survival in devegetated plots for both canopy types. Ninety-four percent of L. castanopsisifolious seeds had disappeared from the vegetated plots after 35 days, versus $91 \%$ from devegetated plots. However, the treatment producing the biggest differences after 35 days for $P$. kwakamii was thinning, with $98 \%$ of seeds disappearing from thinned, a much lower probability of survival than in close canopy plots ( $84 \%$ seeds disappeared after 35 days).

From the images captured by the automatic cameras, we identified two mammal species as the acorn consumers/removers during the observation period. These two species were redbellied squirrel (Callosciurus erythraeus) and Owslon's long-nosed tree squirrel (Dremomys pernyi owstoni). These two species can be seen as potential dispersers of large seeds in the late succession period.

\subsubsection{Seed removal}

The results from Cox regressions indicated that, for both species, removing part of the canopy significantly influenced seed removal (mortality risk) in the study site (Table 1, Fig.2). Results indicated that, for P. kwakamii, seeds in the thinned treatments suffered the highest removal risk (Table 1). Similar results were found for L. castanopsisifolius (Table 1). In addition to the main effects, the interaction between canopy type and understory vegetation cover was non-significant (Table 1).

\begin{tabular}{|c|c|c|c|c|}
\hline$\overline{\text { Treatment }}$ & $\mathrm{df}$ & Hazard ratio $^{1}$ & $\overline{Z^{4}}$ & $P$ \\
\hline \multicolumn{5}{|l|}{ Lithocarpus castanopsisifolius } \\
\hline Thinning2 2 & 1 & 0.70 & -5.11 & $<0.001$ \\
\hline Understory removal $^{3}$ & 1 & 1.05 & 0.73 & 0.466 \\
\hline Thinning $\times$ Vegetation & 1 & 1.18 & 1.69 & 0.091 \\
\hline \multicolumn{5}{|l|}{ Pasania kwakamii } \\
\hline Thinning & 1 & 0.65 & -6.18 & $<0.001$ \\
\hline Understory removal & 1 & 1.04 & 0.66 & 0.509 \\
\hline Thinning $\times$ understory removal & 1 & 1.09 & 0.93 & 0.351 \\
\hline
\end{tabular}

Table 1. Effects of thinning and ground vegetation treatments on the seed hazard (instantaneous mortality risk) based on Cox regressions. Notes: 1) Hazard ratio is defined as the ratio of mortality risk between two factor levels. If hazard ratio $=1$, it indicates equal mortality risk; 2) Risk ratio of thinned relative to unthinned treatment; 3) Risk ratio of devegetated relative to vegetation treatment; 4) Cox regression coefficient.

\subsubsection{Seedling establishment}

Probabilities of successful seedling establishment at day 140 differed among species and treatments. For P. kwakamii, seedlings only successfully established in the unthinned plots (Fig. 3 left panel). For L. castanopsisifolious, there was a small seedling establishment probability in thinned plots, but the success rate was much higher for unthinned plots. (Fig. 3 right panel). No significant difference was detected between vegetated and devegetated plots. 


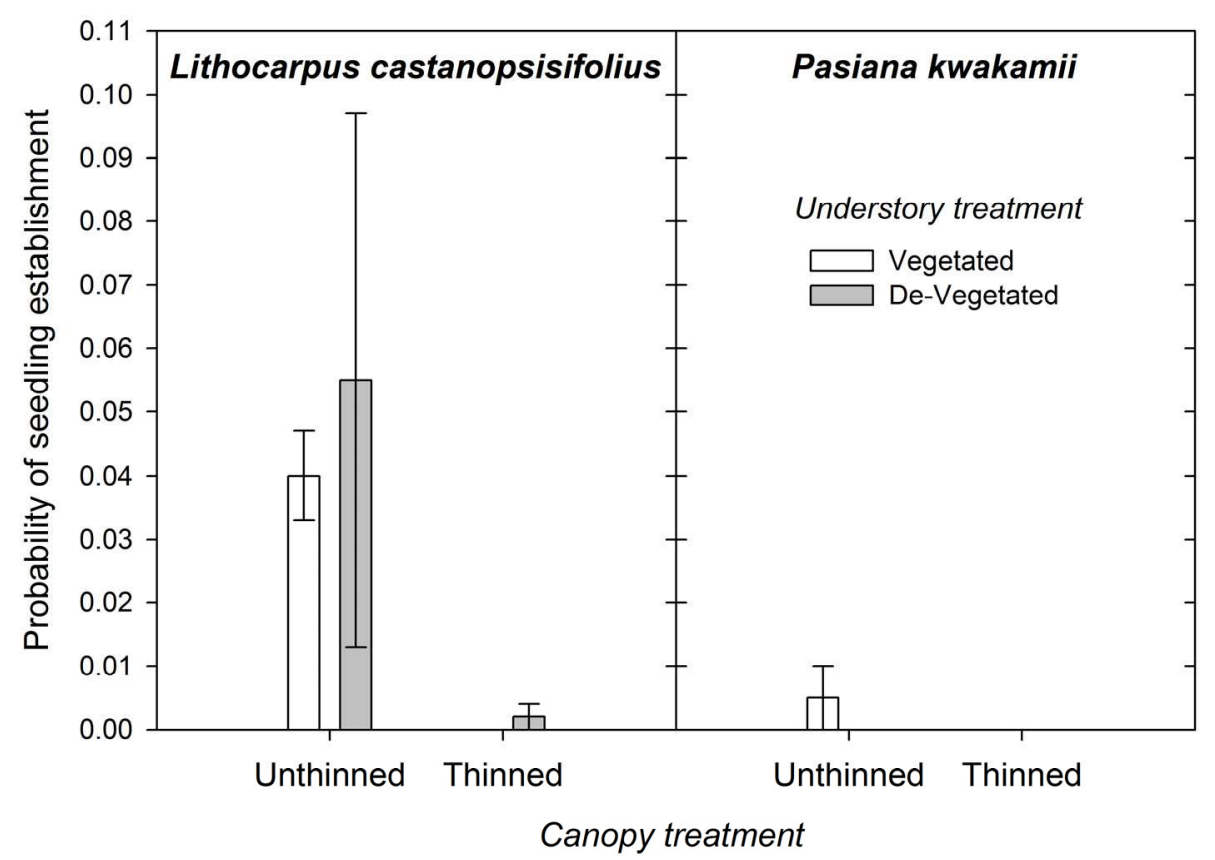

Fig. 3. Probabilities of successful seedling establishment after 140 days of seed planting for Lithocarpus castanopsisifolius (left panel) and Pasania kawakamii (right panel). Error bars represent the mean \pm standard error.

\subsection{Discussion}

Differential seed survival and seedling establishment among species, canopy and ground vegetation conditions were observed. The thinning treatment reduced seedling establishment in both species and significantly reduced seedling survival in both species. In addition, seedling establishment was not significantly affected by removing ground vegetation.

Despite that our results are species-specific, they suggest that keeping canopy vegetation intact may be more effective than removing understory for the two species studied. Survival rates for the unthinned plots were consistently higher than for the thinned plots in either vegetated or devegetated after two weeks of seeding (Figure 2). In contrast, differences in seed survival between the two vegetation types did not show consistent patterns and the difference was rather small. Such results suggest that removing the understory layer may not be as effective as keeping the canopy cover, although understory removal showed a tendency to increase seed survival in L. castanopsisifolius, although statistically not significant.

The observed differences in seed survival may arise from changes in foraging behaviours of seed predators as a result of the forest management treatments. The understory vegetation was rather dense in the study site, especially in the thinned plots. The understory grew rapidly after selective thinning was conducted in 2005. The improved light conditions due to 
thinning were believed to facilitate the rapid growth, which was mostly composed by broadleaf species, such as Schefflera actophylla, and Machilus thunbergii, which are shadetolerant but can take advantage of increased light levels (C.-W. Yu, personal observation). Therefore, thinning could reduce seed survival by favouring understory growth and then providing more protection for seed predators.

In addition, the openness of the canopy layer can also influence the behaviour of seed predators (Boman and Casper, 1995; Schnurr et al., 2004), as well as the effects of understory vegetation (Chambers and MacMahon, 1994; Fenner and Thompson, 2005). The effect of both canopy structure or understory vegetation density on seed survival, however, is somewhat context-dependent (den Ouden, 2004; Hulme \& Kollmann, 2004; Tamura \& Katsuki, 2004). Seed predation may increase or decrease among different microhabitats depending on the composition of seed predators (Schupp et al., 2002; den Ouden, 2004; Hulme \& Kollmann, 2004; Tamura \& Katsuki, 2004). For instance, seed predation by squirrels is reduced in canopy gaps, while predation rates by field mice, Peromyscus mexicanus are higher in canopy gaps (Tamura \& Katsuki, 2004). This may be the case in our study, which showed increases in seed predation in conditions with higher canopy openness after thinning. To try to understand the relationship between seed predators and seedling establishment, the movements of mammals were monitored in a nearby plantation.

Mammalian activities were decreased immediately after thinning treatments (Lin \& Bridgman, 2010). In addition, the photos taken from our automatic cameras in our plots also suggested that major seed predators in the study sites were granivorous animals, including red-bellied Squirrel and Owslon's long-nosed tree squirrel. These animals may also become seed dispersers via scatter-hoarding behaviour. Therefore, they can be reducing the seed survival but increasing seed dispersal rates at the same time. Scatter-hoarding behaviour has been widely observed in squirrels and jays in various forest ecosystems, where instead of consuming the seeds, they moved seeds away and cached the seeds (Vander Wall, 1994; Forget et al., 2004; Zhang et al., 2004). The cached seeds may germinate at later dates. Some of the animals observed by the automatic camera may also function as seedling predators. For example, many rodent species, such as red-bellied squirrels or the Formosan field mouse have been observed to eat seedlings (Young, personal observation). Seed tracking techniques are required to study the details of scatter-hoarding behaviours (Forget et al., 2004), and they could be a future research line at these sites.

In addition of these two species, we are carrying similar experiments for other tree species at the same plots, and our preliminary results indicate that for other species the effects of thinning and understory removal can be the opposite (data not shown). Our experiments are the first ones of these kind in Taiwan, and the species-specific responses of seedling establishment to management activities provide a clear indication of the need to shift from a static conservation in which the "no human action" approach is favoured into a more active restoration strategy. If no action were taken, it can be expected that L. castanopsisifolious will successfully regenerate, and in a lesser way P. kwakamii. Under this scenario, the future tree composition of these stands could be a multi-story canopy in which the Japanese cedar (an alien species) dominates the canopy, with lower layers of L. castanopsisifolius and other similar native species, but in which $P$. kwakamii will remain mostly suppressed. As a consequence, the new state of this forest under a conservation-only strategy would not be 
either the Japanese cedar plantation or the original mixed forest, but a hybrid of both. Only after a major natural disturbance (i.e. a typhoon or a stand-replacing wildfire) this hybrid stand could be transformed into the original mixed forests. Therefore, if this "new ecological state" is to be avoided and the recovery towards the original mixed forest is needed, a program of seeding combined with additional research to improve the regeneration of $P$. kwakamii should be implemented in these stands to ensure that $P$. kwakamii finds favourable conditions to regenerate. However, these activites should be localized and not general through the stands to avoid the inhibitory effect that close canopy or exposed forest floor could have for the regeneration of other important native species.

\section{Conclusions}

The native forests within the elevational range in this experimental area were dominated by Fagaceae and Lauraceae species. These families were, however, rare in the seed rain of the planted forest after thinning (Sun, 2010). Such results suggested a high degree of recruitment limitation in the plantation. Therefore, to facilitate the transition from planted forest to native forest, it is essential to develop management strategies to overcome recruitment limitation of native species in the plantation forest. Our study indicated that for the two species studied, keeping the canopy cover could be an effective management tool to overcome recruitment limitation, suggesting an easy and inexpensive mean for forest restoration. With extensive plantation forests in Taiwan, the management practices could be widely applied to facilitate the regeneration of native species. The next step is to apply such treatments to a broader area to assess the operational costs of such management techniques. The efficiency of these management techniques, however, seems to be species-specific. Other research has shown opposite effects of thinning and vegetation removal in other species at the same sites (data not shown). Therefore, we warn the readers from assuming that the results presented here could be applied to other forests types or regions. The interaction between light availability, soil moisture and species-specific factors for trees (seed size, seed dispersal) and seed predators (foraging behaviour, seed preference) can make the same management have very different results in restoring different sites.

All things considered, our research shows how the shift from passive ecological conservation towards a more active ecological restoration can be successful if enough ecological information on ecosystem structure and function is available. Also, if no active restoration is implemented, the ecological barriers for seedling establishment could prevent these ecosystems from recovery for a long time, generating a new "hybrid" state with elements from both the human-altered (plantation) and original (mixed forest) ecosystems. We suggest that other similar programs monitoring seed survival and seedling establishment should be enacted in other forest regions around the world, especially in tropical forest where little is known about many of the native tree species.

\section{Acknowledgements}

The authors thank Dr. Po-Jen Jiang for his assistance in setting up automatic cameras. We also thank National Taiwan University Experimental Forest for their help during the field work period. This study was supported by a grant to Dr. Biing T. Guan and Dr. Yiching Lin by the Taiwan National Science Council (NSC 97-2313-B-002-041-MY3). 


\section{References}

Adams, W.M. (2004). Against Extinction: The Story of Conservation, Earthscan, ISBN 9781844070565, London, UK.

Andam, K.S.; Ferraro, P.J.; Pfaff, A.; Sanchez-Azofeifa, G.A.; Robalino, J.A. (2008). Measuring the effectiveness of protected area networks in reducing deforestation. Proceedings of the National Academy of Science USA, Vol. 105, pp. 16089-16094, ISSN0027-8424.

Augspurger, C.K. (1984). Light requirements of neotropical tree seedlings: A comparative study of growth and survival. Journal of Ecology, Vol. 72, pp. 777-796, ISSN: 13652745.

Baskin, C.C.; Baskin, J.M. (1998). Seeds: ecology, biogeography, and evolution of dormancy and germination. Academic Press, ISBN 978-0120802609, San Diego, USA.

Bazzaz, F.A., (1996). Plants in Changing Environments: Linking Physiological, Population, and Community Ecology. Cambridge University Press, ISBN 978-0521398435, Cambridge, UK.

Beckage, B.; Clark, J.S. (2005). Does predation contribute to tree diversity? Oecologia, Vol. 143, pp. 458-469. ISSN 0029-8549.

Beckage, B.; Clark, J.S.; Clinton, B.D.; Haines, B.L. (2000). A long-term study of tree seedling recruitment in southern Appalachian forests: the effects of canopy gaps and shrub understories. Canadian Journal of Forest Research, Vol. 30, pp. 1617-1631, ISSN 1208-6037.

Boman, J.S.; Casper, B.B. (1995). Differential Postdispersal Seed Predation in Disturbed and Intact Temperate Forest. American Midland Naturalist, Vol. 134, pp. 107-116, ISSN 0003-0031.

Boufford, D.E.; Hsieh, C.F.; Huang, T.C.; Ohasi, H.; Yang, Y.P.; Lu, S.Y. (eds.) (1996). Flora of Taiwan, 2nd Ed. Editorial Committee of the Flora of Taiwan, ISBN 957-02-7534-0, Taipei, Taiwan, ROC.

Brockerhoff, E.G.; Jactel, H.; Parrotta, J.A.; Quine, C.P.; Sayer, J. (2008). Plantation forests and biodiversity: oxymoron or opportunity? Biodiversity and Conservation, Vol. 17, pp. 925-951. ISSN 0960- 3115.

Brokaw, N.; Busing, R.T. (2000). Niche versus chance and tree diversity in forest gaps. Trends in Ecology and Evolution, Vol. 15, pp. 183-188. ISSN 0169-5347.

Butchart, S.H.M.; et al. (2010) Global biodiversity: indicators of recent declines. Science, Vol. 328, pp. 1164-1168, ISSN 0036-8075.

Butchart, S. H. M.; Stattersfield, A. J.; Collar, N. J. (2006). How many bird extinctions have we prevented? Oryx, Vol 40, pp. 266-278, ISSN: 0030-6053.

Caccia, F.D.; Ballare, C.L. (1998). Effects of tree cover, understory vegetation, and litter on regeneration of Douglas-fir (Pseudotsuga menziesii) in southwestern Argentina. Canadian Journal of Forest Research, Vol. 28, 683-692, ISSN 1208-6037.

Chambers, J.C.; MacMahon, J.A. (1994). A day in the life of a seed: movements and fates of seeds and their implications for natural and managed systems. Annual Review of Ecology and Systematics, Vol. 25, pp. 263-292, ISSN 0066-4162.

Chazdon, R.L. (2008). Beyond deforestation: restoring forests and ecosystem services on degraded lands. Science, Vol. 320, pp. 1458-1460, ISSN 0036-8075.

Clements, F.E. (1916). Plant succession: an analysis of the development of vegetation. Carnegie Institute of Washington, Publication No. 242. Washington DC, USA. 
Clewell, A.F.; Aronson, J. (2007). Ecological Restoration: Principles, Values, and Structure of an Emerging Profession. Island Press, ISBN 978-1597261692. Washington DC, USA.

Connell, J.H. (1971). On the role of natural enemies in preventing competitive exclusion in some marine animals and in rain forest trees. In: Dynamics of populations, den Boer, P.J.; Gradwell, G.R. (eds.), pp. 298-310, Centre for Agricultural Publishing and Documentation, Wageningen, The Netherlands.

Cox, D.R. (1972). Regression models and life tables. Journal of the Royal Statistical Society. Series B (Methodological), Vol. 34, pp. 187-220, ISSN: 0035-9246.

den Ouden, J. (2004). Jays, Mice and Oaks: Predation and Dispersal of Quercus robur and C. petraea in North-Western Europe In: Seed Fate: Predation, Dispersal and Seedling Establishment, Forget, P.M.; Lambert, J.E.; Hulme, P.E.; Vander Wall, S.B. (Eds.), CABI International, Wallingford, UK, ISBN 978-0851998060.

Fenner, M.; Thompson, K. (2005). The ecology of seeds. Cambridge University Press, Cambridge, UK. ISBN 978-0521653688.

Forget, P.M., Lambert, J.E., Hulme, P.E., Vander Wall, S.B. (Eds.), 2004. Seed Fate: Predation, Dispersal and Seedling Establishment. CABI International, Wallingford, UK, ISBN: 978- 0851998060.

Gaston, K.J.; Jackson, S.E.; Cantu-Salazar, L.; Cruz-Pinon, G. (2008). The Ecological Performance of Protected Areas. Annual Review of Ecology, Evolution and Systematics, Vol. 39, pp. 93-113, ISSN 1545-2069.

Gove, A.D.; Majer, J.D.; Rico-Gray, V. (2005). Methods for conservation outside of formal reserve systems: The case of ants in the seasonally dry tropics of Veracruz, Mexico. Biological Conservation, Vol. 126, pp. 328-338, ISSN 0006-3207.

Hobbs, R.J.; Norton, D.A. (1996). Towards a conceptual framework for restoration ecology. Restoration Ecology, Vol. 4, pp. 93-110, ISSN 1061-2971.

Hulme, P.E.; Kollmann, J. (2004). Seed Predator Guilds, Spatial Variation in Post-Dispersal Seed Predation and Potential Effects on Plant Demography - a Temperate Perspective. In: Seed Fate: Predation, Dispersal and Seedling Establishment. Forget, P.M.; Lambert, J.E.; Hulme, P.E.; Vander Wall, S.B. (Eds.), CABI International, Wallingford, UK, ISBN: 978- 0851998060.

Hsu, M.J.; Agoramoorthy, G. (1997). Wildlife conservation in Taiwan. Conservation Biology, Vol. 11, pp. 834-836, ISSN 0888-8892.

Hsu, M.J.; Agoramoorthy, G. (1999). Conserving the biodiversity of Kenting National Park, Taiwan: Present status and future challenges. In: Proceedings of the Symposium on Biodiversity - 1999. Lin, Y.S. (ed.) pp. 62-72, Council of Agriculture, Executive Yuan, Taipei, Taiwan.

Janzen, D.H. (1970). Herbivores and the number of tree species in tropical forests. American Naturalist, Vol. 104, pp. 501-528, ISSN 0003-0147.

Janzen, D.H. (1971). Seed predation by animals. Annual Review of Ecology and Systematycs, Vol. 2, pp. 465-493, ISSN 0066-4162.

Jordan, W.R.; Gilpin, M.E.; Aber, J. (Eds.) (1987) Restoration Ecology: A Synthetic Approach to Ecological Research. Cambridge University Press, ISBN 978-0521337281, Cambridge, UK.

Kimmins, J.P.; Blanco, J.A.; Seely, B.; Welham, C. \& Scoullar, K. (2010). Forecasting Forest Futures: A Hybrid Modelling Approach to the Assessment of Sustainability of 
Forest Ecosystems and their Values. Earthscan Ltd., ISBN 978-1-84407-922-3, London, UK.

Laliberte, A.S.; Ripple, W.J. (2004). Range contractions of North American carnivores and ungulates. BioScience, Vol. 54, pp. 123-138, ISSN 0006-3568.

Leck, M.A.; Parker, V.T.; Simpson, R.L. (Eds.) (2008). Seedling Ecology and Evolution, Cambridge University Press Cambridge, UK, ISBN: 978-0521873055.

Lewontin, R.C. (1969). Meaning of stability. Brookhaven Symposia in Biology, Vol. 22, pp. 1324, ISSN 0068-2799.

Lin, L.-K.; Bridgman, C.L. (2010). Effect of differential thinning on habitat selection of birds and mammals in a Cryptomeria japonica plantations In: Symposium of thinning effects on biodiversity and ecosystem functions. Taiwan Forestry Research Institute, Taichung, Taiwan (R.O.C.).

Lu, S.-Y.; Cheng, J.D.; Brooks, K.N. (2001). Managing forests for watershed protection in Taiwan. Forest Ecology and Management, Vol. 143, pp. 77-85, ISSN 0378-1127.

Masaki, T.; Osumi, K.; Takahashi, K.; Hoshizaki, K.; Matsune, K.; Suzuki, W. (2007). Effects of microenvironmental heterogeneity on the seed-to-seedling process and tree coexistence in a riparian forest. Ecological Research, Vol. 22, pp. 724-734, ISSN 00139351.

National Taiwan University Experimental Forest (NTUEF) (2011). The Experimental Forest College of Bioresources and Agriculture (Weather Data. Retrieved on 2011/4/8 from http:/ / www.exfo.ntu.edu.tw/cht/05teaching/

Naveh, Z. (1994). From biodiversity to ecodiversity: a landscape-ecology approach to conservation and restoration. Restoration Ecology, Vol. 2, pp. 180-189, ISSN 1061-2971.

Nellemann, C.; Corcoran, E. (Eds.) (2010). Dead Planet, Living Planet - Biodiversity and Ecosystem Restoration for Sustainable Development: A Rapid Response Assessment. United Nations Environment Programme, ISBN 978-82-7701-083-0, Nairobi, Kenya.

Noss, R.F.; LaRoe, E.T.; Scott. J.M. (1995). Endangered ecosystems of the United States: a preliminary assessment of loss and degradation. Biological Report 28, U.S. Department of the Interior, National Biological Service, Washington, D.C., USA.

Odum E.P. 1969. The strategy of ecosystem development. Science, Vol. 164, pp. 262-270, ISSN 0036-8075.

Pickett, S.T.A.; McDonnell, M.J.M. (1989). Changing perspectives in community dynamics atheory of successional forces. Trends in ecology and evolution, Vol. 4, pp. 241-245, ISSN 0169-5347.

Pickett, S.T.A.; Ostfield, R.S. (1995). The shifting paradigm in ecology. In: A New Century for Natural Resources Management, R.L. Knight, S.F. Bates (Eds.), 261-278. Island Press, ISBN: 978-1559632621, Washington DC, USA.

R Development Core Team, 2010. R: A language and environment for statistical computing. R Foundation for Statistical Computing, Vienna, Austria.

Runte, A. (1997). National Parks: the American experience $3^{\text {rd }}$ Ed. University of Nebraska Press, ISBN: 978-0803289635, Lincoln, USA.

Sala O. E. et al. (2000). Global biodiversity scenarios for the year 2100. Science, Vol. 287, pp. 1770-1774, ISSN 0036-8075.

Schnurr, J.L.; Canham, C.D.; Ostfeld, R.S.; Inouye, R.S. (2004). Neighborhood analyses of small-mammal dynamics: Impacts on seed predation and seedling establishment. Ecology, Vol. 85, pp. 741-755, ISSN 0012-9658. 
Schupp, E.W.; Milleron, T.; Russo, S.E. (2002). Dissemination limitation and the origin and maintenance of species-rich tropical forests. In: Seed Dispersal and Frugivory: Ecology, Evolution and Conservation, Levey, pp. 19-34. D.J.; Silva, W.R.; Galetti, M. (Eds.). CABI International, Wallingford, UK, ISBN: 978- 0851998060.

Scott J.M.; Davis, F.W.; McGhie, R.G.; Wright, R.G.; Groves, C.; Estes, J. (2001). Nature reserves: do they capture the full range of America's biological diversity? Ecological applications, Vol. 11, pp. 999-1007, ISSN 1051-0761.

Smit, C.; Gusberti, M.; Müller-Schärer, H. (2006). Safe for saplings; safe for seeds? Forest Ecology and Management, Vol. 237, pp. 471-477, ISSN: 0378-1127.

Soulé, M.E.; Terborgh, J. (1999). Conserving nature at regional and continental scales-a scientific program for North America. BioScience, Vol. 49, pp. 809-817, ISSN 00063568 .

Sun, I.-F. (2010). Effects of thinning on forest regeneration and restoration In: Symposium of thinning effects on biodiversity and ecosystem functions. Taiwan Forestry Research Institute, Taichung, Taiwan (R.O.C.).

Tamura, N.; Katsuki, T. (2004). Walnut Seed Dispersal: Mixed Effects of Tree Squirrels and Field Mice with Different Hoarding Ability. In: Seed Fate: Predation, Dispersal and Seedling Establishment, Forget, P.M., Lambert, J.E., Hulme, P.E., Vander Wall, S.B. (Eds.), CABI International, Wallingford, UK, ISBN: 978- 0851998060.

Vander Wall, S.B. (1994). Seed fate pathways of antelope bitterbrush: Dispersal by seedcaching yellow pine chipmunks. Ecology, Vol. 75, pp. 1911-1926.

Waldman, N. 2001. They came from the Bronx: how the buffalo were saved from extinction. Boyds Mill Press, ISBN 978-1563978913. Honesdale, USA.

Wallington, T.J.; Hobbs, R.J.; Moore, S.A. (2005). Implications of current ecological thinking for biodiversity conservation: a review of the salient issues. Ecology and Society, Vol. 10, article 15, ISSN 1708-3087.

Wang, D.H. (1997). Perspectives on forestry resources managemen. Part III. Republic of China, Vol 2. Asian Productivite Organization, Tokyo, Japan, pp. 153-165.

Wu, J.; Loucks, O.L. (1995). From balance of nature to heirarchical patch dynamics: a paradigm shift in ecology. The Quarterly Review of Biology, Vol. 70, pp. 439-466, ISSN 0033-5770.

Zahawi, R.A.; Augspurger, C.K. (2006). Tropical forest restoration: Tree islands as recruitment foci in degraded lands of Honduras. Ecological Applications, Vol. 16, pp. 464-478, ISSN 1051-0761.

Zahawi, R.A.; Holl, K.D. (2009). Comparing the Performance of tree stakes and seedlings to restore abandoned tropical pastures. Restoration Ecology, Vol. 17, pp. 854-864, ISSN 1061-2971.

Zhang, Z.-B.; Xiao, Z.-S.; Li, H.-J. (2004). Impact of Small Rodents on Tree Seeds in Temperate and Subtropical Forests, China. In: Seed Fate: Predation, Dispersal and Seedling Establishment, Forget, P.M., Lambert, J.E., Hulme, P.E., Vander Wall, S.B. (Eds.) CABI International, Wallingford, UK, ISBN: 978- 0851998060. 


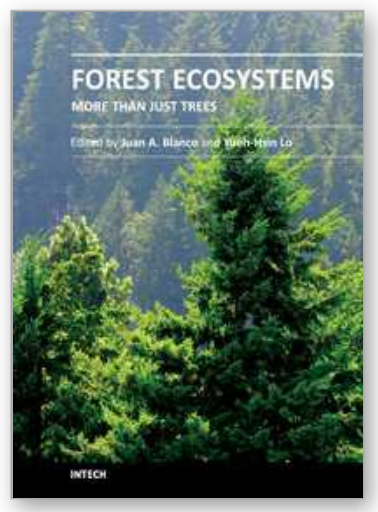

\section{Forest Ecosystems - More than Just Trees}

Edited by Dr Juan A. Blanco

ISBN 978-953-51-0202-1

Hard cover, 464 pages

Publisher InTech

Published online 07, March, 2012

Published in print edition March, 2012

The common idea for many people is that forests are just a collection of trees. However, they are much more than that. They are a complex, functional system of interacting and often interdependent biological, physical, and chemical components, the biological part of which has evolved to perpetuate itself. This complexity produces combinations of climate, soils, trees and plant species unique to each site, resulting in hundreds of different forest types around the world. Logically, trees are an important component for the research in forest ecosystems, but the wide variety of other life forms and abiotic components in most forests means that other elements, such as wildlife or soil nutrients, should also be the focal point in ecological studies and management plans to be carried out in forest ecosystems. In this book, the readers can find the latest research related to forest ecosystems but with a different twist. The research described here is not just on trees and is focused on the other components, structures and functions that are usually overshadowed by the focus on trees, but are equally important to maintain the diversity, function and services provided by forests. The first section of this book explores the structure and biodiversity of forest ecosystems, whereas the second section reviews the research done on ecosystem structure and functioning. The third and last section explores the issues related to forest management as an ecosystem-level activity, all of them from the perspective of the other parts of a forest.

\section{How to reference}

In order to correctly reference this scholarly work, feel free to copy and paste the following:

Yueh-Hsin Lo, Yi-Ching Lin, Juan A. Blanco, Chih-Wei Yu and Biing T. Guan (2012). Moving from Ecological Conservation to Restoration: An Example from Central Taiwan, Asia, Forest Ecosystems - More than Just Trees, Dr Juan A. Blanco (Ed.), ISBN: 978-953-51-0202-1, InTech, Available from:

http://www.intechopen.com/books/forest-ecosystems-more-than-just-trees/moving-from-ecologicalconservation-to-restoration-an-example-from-central-taiwan-asia

\section{INTECH}

open science | open minds

\section{InTech Europe}

University Campus STeP Ri

Slavka Krautzeka 83/A

51000 Rijeka, Croatia

Phone: +385 (51) 770447

\section{InTech China}

Unit 405, Office Block, Hotel Equatorial Shanghai

No.65, Yan An Road (West), Shanghai, 200040, China

中国上海市延安西路65号上海国际贵都大饭店办公楼 405 单元

Phone: +86-21-62489820 
Fax: +385 (51) 686166

Fax: +86-21-62489821

www.intechopen.com 
(C) 2012 The Author(s). Licensee IntechOpen. This is an open access article distributed under the terms of the Creative Commons Attribution 3.0 License, which permits unrestricted use, distribution, and reproduction in any medium, provided the original work is properly cited. 